\title{
Inhibitory effect of metals on animal and plant glutathione transferases $\#$
}

Dirk Dobritzsch ${ }^{1,4 *}$, Konstantin Grancharov², Corinna Hermsen ${ }^{1}$, Gerd-Joachim Krauss ${ }^{1}$, Dirk Schaumlöffel ${ }^{3}$

$5 \quad{ }^{1}$ Martin-Luther-Universität Halle-Wittenberg, Institut für Biochemie und Biotechnologie, Abteilung Ökologische und Pflanzen-Biochemie, Kurt-Mothes-Str. 3, 06120 Halle (Saale), Germany

${ }^{2}$ Institute of Molecular Biology, Dept. Biochemical Pharmacology and Drug Design, Bulgarian Academy of Sciences, 1113 Sofia, Bulgaria

${ }^{3}$ CNRS / Université de Pau et des Pays de l'Adour / E2S UPPA, Institut des Sciences Analytiques et de PhysicoChimie pour l'Environnement et les Matériaux, UMR 5254, 64000 Pau, France

${ }^{4}$ Present address: Martin-Luther-Universität Halle-Wittenberg, Core Facility Proteomic Mass Spectrometry, Proteinzentrum Charles Tanford, Kurt-Mothes-Str. 3a, 06120 Halle (Saale), Germany

*corresponding author: dirk.dobritzsch@biochemtech.uni-halle.de

"Accepted manuscript :

15 Dobritzsch, D., Grancharov, K., Hermsen, C., Krauß, G.-J., Schaumlöffel, D. (2020)

Inhibitory effect of metals on animal and plant glutathione transferases.

J. Trace Elem. Med. Biol., 57, 48-56

https://doi.org/10.1016/i.jtemb.2019.09.007

\section{Abstract}

20 Glutathione transferases (GSTs) represent a widespread enzyme superfamily in eukaryotes and prokaryotes catalyzing different reactions with endogenous and xenobiotic substrates such as organic pollutants. The latter are often found together with metal contamination in the environment. Besides performing of essential functions, GSTs protect cells by conjugation of glutathione with various reactive electrophiles. The interference of toxic metals with this functionality of GSTs may have unpredictable toxicological consequences for the organisms. In this review results from the recent literature are summarized and discussed describing the ability of metals to inhibit intracellular detoxification processes in animals and plants.

\section{Keywords}

Glutathione transferase, metal, man, animal, plant

\section{Introduction}

Metal pollutants are one of the greatest challenges to the environment and human health. Metals enter the biosphere by natural processes (e.g. volcanism, weathering) and human activities such as mining, fuel combustion and many other industrial processes [1]. The toxicological relevance of metals depends on their chemical species, i.e. the chemical compound and the oxidation state of the metal, as well as the bioavailability of these metal species for organisms. In the environment biogeochemical transformations of metal species have to be taken into account. For example in aquatic systems the inorganic mercury species $\mathrm{Hg}^{2+}$ can be transformed by microorganisms into highly toxic methylmercury $(\mathrm{MeHg}$ ) that represents the most environmental concern regarding this element [2]. Another example are acid mine drainage waters which are acidic effluents from abandoned mines which can contain very high amounts of arsenic. Biogeochemical processes involving microorganisms oxidize arsenite $\left(\mathrm{AsO}_{3}{ }^{3-}\right)$ to arsenate $\left(\mathrm{AsO}_{4}{ }^{3-}\right)$ together 
with the oxidation of iron $\left(\mathrm{Fe}^{2+}\right.$ to $\left.\mathrm{Fe}^{3+}\right)$ resulting in As-Fe coprecipitation and thus the formation of the As(V)$\mathrm{Fe}$ (III) hydroxysulfate sediments which reduce drastically the bioavailability of As [3].

Beside other toxic effects, metals can for example interfere with intracellular detoxification mechanisms of organic pollutants and thus amplify the toxicity of these compounds. Glutathione transferases (GSTs) play a key role in the detoxification of organic xenobiotics as well as endobiotic metabolites. When metals enter an organism, protective mechanism against oxidative stress and other detrimental effects involve also the increase of GST activity (for example in plants see [4]). However, there is increasing evidence that metals at toxic concentrations affect GSTs either by direct inhibition of enzyme activity or indirectly by decreasing the concentration of the GST substrate reduced glutathione (GSH, Figure 1). The latter is involved in the cellular defense against metals by high chemical affinity to bind to soft metal ions, like $\mathrm{Hg}^{2+}$ and $\mathrm{Cd}^{2+}$ and/or metalinduced oxidative stress by changing the $\operatorname{GSH} / \mathrm{GSSG}$ equilibrium $[5,6]$. As consequence, metal-induced inhibition of GSTs interferes with intracellular detoxification of organic xenobiotics or endobiotic metabolites which may lead to unpredictable toxicological consequences for organisms. This fact is of particular importance as under ecological conditions organic contaminants are often found together with metal contaminants $[7,8]$.

Our review gives a brief overview on the role of GST in organisms and discusses recent data for both in vivo and in vitro inhibitory effects on animal and plant GSTs by toxic metals.

\section{Characteristics of glutathione transferase and its role in biological systems}

60 The glutathione transferase (formerly reported as glutathione S-transferases, EC 2.5.1.18) supergene family is composed of several isoenzymes which are involved in phase II detoxification of electrophilic xenobiotics and endogenous compounds in procaryotes $[9,10]$ and eucaryotes including non-mammalian vertebrates [11], mammals and humans [12,13] and plants [14-16]. GSTs catalyze the conjugation of organic compounds to the nucleophilic sulfur of the major intracellular thiol compound, glutathione (GSH) rendering them more hydrophilic and less toxic.

Recently, a graphical overview of the different classes of glutathione transferase was proposed by Kumar and Trivedi [16] (Figure 2). At least 16 genes encode GSTs in the mammalian cytosol, whereas for plants a number of 40-60 is proposed [17]. They are mostly dimeric enzymes of 45-55 kDa and include eleven classes of mammalian cytosolic GSTs: A (alpha), M (mu), P (pie), C (chie), D (delta), B( beta), E (epsilon), O (omega), S (sigma), $T$ (theta), and Z (zeta), both latter classes are found in plants, too . To date six classes of plant cytosolic GSTs have been identified Z (zeta), T (theta), F (phi), U (tau), L (lambda), and DHAR (dehydroascorbate reductase)) $[17,18]$. Except for $L$ (lambda) and DHAR (dehydroascorbate reductase), which are monomers, plant GSTs also occur as dimers. In plants phi and tau class GSTs catalyze peroxidase reactions, while zeta class GSTs catalyze isomerase reactions [19]. In each class, multiple isoenzymes were found whereas tandem duplication can be regarded as the major expansion mechanism [20].

In mammals, cell specific distribution of GST isoforms has been reported, as GSTP in the biliary tract and GSTA in hepatocytes [21]. A high expression of cytosolic GST P, M, A, and T classes in various tumor cells has been observed [22, 23]. Typical GST-catalyzed reactions include: i) nucleophilic aromatic substitution, ii) Michaeltype addition, iii) nucleophilic addition to epoxides, iv) hydroperoxide reduction, and v) double bond isomerization[24].

Besides detoxification, GSTs perform other essential functions in animal and plant cells [25, 26]. GSTs have regulatory roles in cellular signaling (e.g. by mediating S-glutathionylation of specific clusters of target proteins and in reactions that define a negative regulatory role in some kinase pathways through ligand or protein:protein interactions, example for the role of GSTs' in cellular signaling [27] and inactivate 
endogenous products of oxidative stress (such as 13-oxooctadecadienoic acid and 4-hydroxynonenal). These compounds are known to elicit cellular responses, such as apoptosis and cell proliferation. Conjugation with GSH eliminates these effects [28, 29].

GSTs also have non-catalytic functions. Originally, GSTs were identified as "ligandins" due to their ability to bind and transport across the plasma membrane organic molecules that are not enzyme substrates [30]; e.g. steroids, thyroid hormones, bile acids, bilirubin and heme [31]. This however might just be some sort of cross reaction due to the chemical abilities rather than a specific, regulated function of GSTs.

Plant GSTs are active as hormone and flavonoid ligandins [26, 32]. Tau-type GSTs are able to bind GSH conjugates of fatty acids [33].

Probably, plant GSTs are involved in in vivo synthesis of sulfur-containing secondary metabolites such as volatiles and glucosinolates as well as in conjugation, transport and storage of reactive oxylipins, phenolics and flavonoids [14, 15, 34]. During plant developmental processes and stress response GSTs play also an important role in the regulation of cellular detoxification processes under different light conditions [35]. Gullner et al. [36] summarize diverse roles of plant GST isoenzymes in the interaction of plants with pathogenic bacteria and fungi.

100 In mammalian systems, GSTs participate in cell signaling through protein-protein interactions with many regulatory signaling proteins, such as c-Jun $\mathrm{N}$-terminal kinase (JNK) and apoptosis signal regulating kinase ASK1 [37]. Activation of these kinases leads either to apoptosis or cellular proliferation [38]. GSTs can inhibit JNK and ASK1 activity by forming complexes [23, 39]. Thus, GSTs play a decisive cytoprotective role against carcinogenic electrophiles and products of oxidative stress. Perturbation of their function may have unpredictable toxicological consequences. Previously the concept of GST inhibition in ameliorating anticancer drug resistance was reviewed [40, 41]. In recent years novel functions of GSTs have been suggested such as regulation of cell signaling pathways and ion channels [25].

\section{Inhibition of GST by toxic metals in man, animals and plants}

A principal function of the GST enzymes is the detoxification of xenobiotic substances by catalysing their conjugation with glutathione. This GST activity can be interfered by metals which may lead to detrimental toxic effects for the organism (Figure 1). Data on in vivo and in vitro inhibitory effects of metal on GSTs are summarized in Table 1. In most of the studies the influence of toxic metals or surplus essential biometals to total GST activity was determined by measuring the absorbance $(340 \mathrm{~nm})$ of the conjugation of the model xenobiotic 1-chloro-2,4-dinitrobenzene (CDNB) with reduced GSH (Figure 3), usually according to a method

115 published by Habig et al.[42]. The increase of absorbance is directly related to the GST activity. The method shows a good reproducibility, when summarizing the different studies reviewed here. The overall standard deviation for GST activity determination was around 3\% in most of the studies. In the following sections the metals are listed according to Periodic Table of the Elements with increasing average atomic mass from light to heavy.

120 GST inhibition in animals including men

Although most studies have been conducted with laboratory animals or fish, here we report published effects that will obviously occur in all types of animals, including humans. Although the qualitative and quantitative expression of the effects may vary greatly according to the type of organism and its physiological state, as well as the type of metals and mode of application.

\section{Aluminium}

Aluminium can be found ubiquitously in the environment either naturally or introduced due to human activity. This metal has no known essential biological function. However, it has the potential to cause neurotoxic effects in man and animals. For example, Al has been connected to neurodegenerative diseases 
such as Alzheimer's and Parkinson's disease, as well as amyotrophic lateral sclerosis. Therefore, the few studies describing Al influence on GST activity have been mainly done in brain tissue. A recent study of Singla and Dhawan [43] detected a highly significant decrease of GST activity by $68 \%$ in cerebellum and to $41 \%$ in cerebrum of male Sprague Dawley rats after oral administration of $\mathrm{AlCl}_{3}$ at a daily dose of $100 \mathrm{mg} \mathrm{kg}^{-1}$ for a total duration of 8 weeks. Unfortunately, the used GST conjugate was not mentioned which limits the comparability with other studies. However, these results confirmed an earlier study of Sharma et al.[44] who measured a decrease of GST activity (CDNB conjugate) by $24 \%$ in brains of female Wistar rats after oral administration of $\mathrm{AlCl}_{3}\left(172.5 \mathrm{mg} \mathrm{kg}^{-1} \mathrm{day}^{-1}\right)$. Even at lower doses of $\mathrm{AlCl}_{3}$ (orally $34 \mathrm{mg} \mathrm{kg}^{-1} \mathrm{day}^{-1}$ ) a decrease of GST activity (p-nitrobenzylchloride conjugate) to $19-24 \%$ was detected in plasma, liver, kidney, testes but not brain of male Sprague Dawley rats [45].

140 Chromium

$\mathrm{Cr}^{\text {III }}$ was considered to be required as a trace element in metabolism [46] but results of new studies indicate that chromium currently can only be considered pharmacologically active with beneficial effects have not been definitively shown to occur in animals [47]. Hexavalent chromium easily enters the cell where it is reduced to trivalent chromium compounds by thiols and cytochrome P450-dependent monooxygenases 145 (P450-MO) [48]. $\mathrm{Cr}^{\mathrm{VI}}$ is very toxic and mutagenic [49]. The coordinated regulation and expression of both enzyme systems GST and P450-MO could result in diminished detoxification capacity of the organism, and severe toxicity of $\mathrm{Cr}^{\mathrm{Vl}}$ compounds. Exposure of the frog Rana ridibunda to chromium (10 ppm K ${ }_{2} \mathrm{Cr}_{2} \mathrm{O}_{7}, 14$ days) caused decreased liver (58\%) and kidney (56\%) GST activities [50]. Similar decline has been also reported for P450-MO.

150 Copper

In low concentrations copper is an essential micronutrient. Copper-containing proteins play a role in energy production, signalling and proliferation. Copper deficiency or excess can lead to acute or chronic toxicity triggered by redox-dependent chelation and regulatory mechanisms. For humans, the toxicity limit is more than $10 \mu \mathrm{M},[51,52]$. Excess bioavailable copper thus acts as a genotoxic pollutant and leads to oxidative stress, DNA and protein damage. $\mathrm{CuSO}_{4}$ significantly inhibited GST activity in the gill homogenate of Oncorhynchus mykiss (rainbow trout, [53] and as recently shown in the larvae of the insect Protaetia brevitarsis which play an important role for composting and rotting of fungal and plant residues [54]. In the latter case, firstly an increase of GST activity was observed after 7 days of $\mathrm{Cu}$ exposure followed by a significant decrease after $28 \mathrm{~d}$. Letelier et al. [55] reported that $\mathrm{Cu}^{2+}$ either alone or in the presence of ascorbate (ROS generating system) produced dose- and time-dependent inactivation of GST in rat liver cytosol. Copper significantly modified GST affinity to $G S H,\left(V_{\max } \downarrow, K_{m} \uparrow\right)$ while substrate affinity for xenobiotics remained unchanged. The major mechanism of $\mathrm{Cu}^{2+}$-induced GST inhibition is evidenced to oxidation of its thiol groups and not direct binding to thiol groups.

\section{Arsenic}

165 Arsenic is one of the most harmful metalloids in the environment. Chronic exposure to $\mathrm{AsO}_{3}{ }^{3-i s}$ associated with oxidative stress and increased risk of cancer (skin, bladder, and lung). Swiss mice exposed to arsenic $\left(\mathrm{NaAsO}_{2}, 10 \mathrm{mg} \times \mathrm{kg}^{-1}, 2\right.$ days, orally) showed accumulation in cardiac and renal tissues, accompanied with significant reduction of antioxidant enzyme activities [56, 57]. Also, cardiac (53\%) and renal (63\%) GST activities were reduced. Chronic exposure of $\mathrm{C} 57 \mathrm{~B} 16$ mice to low As levels ( $50 \mathrm{ppb}, \mathrm{NaAsO}_{2}, 4$ weeks) fully

170 blocked GST- $\omega$ expression in the lung-lining fluid [58]. Arsenic at low concentrations $\left(500 \mu \mathrm{g} \times \mathrm{L}^{-1}\right.$ of $\mathrm{As}_{2} \mathrm{O}_{3}, 7$ days) interfered with antioxidant system of the polychaete Laeonereis acuta. Thus, $48 \%$ lower conjugation capacity of GST compared to controls was observed [59].

\section{Antimony}

In the environment natural concentration of the toxic metalloid antimony is low. However, Sb may occur on 175 higher levels at industrial sites such as mining and processing which raises concerns about human and environmental exposure [60]. Among a series of metals tested for their effects toward GST from human 
erythrocytes, trivalent antimony ( $\mathrm{Sb}^{3+}$, antimony potassium tartrate) was found to be the most efficient inhibitor $\left(\mathrm{IC}_{50}: 50 \mu \mathrm{M}\right)$, followed by $\mathrm{Hg}^{2+}, \mathrm{Cu}^{2+}, \mathrm{Cd}^{2+}, \mathrm{Cr}^{3+}$ and $\mathrm{Fe}^{2+}[61]$. While $\mathrm{Sb}^{3+}$ was a competitive inhibitor towards CDNB ( $\left.\mathrm{K}_{\mathrm{i}}: 18 \mu \mathrm{M}\right)$ ), evidenced by interaction of $\mathrm{Sb}^{3+}$ with $\mathrm{GSH}, \mathrm{Sb}^{5+}$ failed to exert any effect on GST.

\section{Selenium}

Selenium is an essential trace element but at high concentrations it becomes toxic. For example, Se toxicity to aquatic organisms has been studied with respect to the GST activity by Gobi et al. [62] in gill and liver cytosols of the fish Oreochromis mossambicus native to southern Africa. In liver GST activity decreased about $20 \%$ when exposed to $100 \mu \mathrm{g} / \mathrm{L}$ Se in comparison to water only (control) for periods of $96 \mathrm{~h}$. Interestingly, at the same Se concentration the GST activity in gill increased by approximately $30 \%$. One conceivable hypothesis is that Se supplementation leading to an increase of GPXs activities which may enable a decrease of GST activity / GSH synthesis to minimize efforts for antioxidant capacity.

\section{Tellurium}

The influence of tellurium at toxic concentrations on GST activity in animal tissue has been rarely 190 investigated. Tellurium, a rare element of raising importance, occurs in dusts from blasts furnace refining of lead. Given to mice (orally, 15 days, $2 \mathrm{mg} \times \mathrm{kg}^{-1}$, sodium salt), it caused dose-dependent decrease of activity of GSH and antioxidant enzymes as well as reduced GST activity in cerebrum (37\%), cerebellum (26\%) and brain stem (29\%) [63].

\section{Silver}

195 Silver levels are high in mineral rich areas and polluted soils. The monovalent silver ions reduce cell viability. In all inhibitory studies referred here, $\mathrm{Ag}^{+}$shows the highest inhibitory effect to GSTs. Using purified rainbow trout erythrocytes the in vitro effects of various metal ions on GST activities were measured [64]. Inhibition constant (Ki values) and IC50 values (concentration of inhibitor necessary to halve the reaction rate of an enzyme-catalyzed reaction) demonstrate that $\mathrm{Ag}^{+}$show the highest inhibitory effect. But, $\mathrm{Cd}^{2+}$ and $\mathrm{Cr}^{2+}$

200 inhibited the GST strongly, too (Tab. 1). GST in muscle tissue from Van Lake fish (Chalcalburnus tarichii) was inhibited mostly strong in a non-competitive manner by $\mathrm{Ag}^{+}$, but also by other metals (Tab.1). $\mathrm{Cd}^{2+}, \mathrm{Co}^{2+}$ and $\mathrm{Fe}^{2+}$ caused no inhibitory effect [65]. Similar results are shown for Van Lake fish gills [66]. Highly purified GST from turkey liver is inhibited in the following order: $\mathrm{Ag}^{+}>\mathrm{Cu}^{2+}>\mathrm{Hg}^{2+}[67]$.

Within the last decades the use of nanomaterials in various products has increased. Among different

nanomaterials, silver nanoparticles (AgNPs) are extensively used in many commercial products [68]. Thus, AgNPs will reach the environment and cause effects at various levels in aquatic organisms [69] or soil organisms [70]. The induction of GSTs mRNA triggered by Cd and AgNPs seems to show that GST are important for defense in aquatic organisms [71]. However, change of GST activity was not significant with increasing concentration of AgNPs in Folsomia candida (Collembola) but effects of AgNPs is similar to the one 210 from $\mathrm{AgNO}_{3}[70]$.

\section{Cadmium}

Cadmium, one of the most hazardous pollutants, can be accumulated in aquatic organisms. The gills of fishes are major targets for acute metal toxicity in these organisms due to their permanent contact with water contaminants. Long term ( 2 weeks) low-level $\left(2 \mu \mathrm{g} \times \mathrm{L}^{-1}\right)$ exposure to $\mathrm{Cd}^{2+}$ led to a distinct decrease of GST 215 activity in gills (> 80\%), but also in digestive glands (>60\%) of the freshwater crayfish Astacus astacus [72]. In $\mathrm{Cd}^{2+}$ exposed freshwater crab (Sinopotamon yangtsekiense) GSH and antioxidant enzymes activities were gradually reduced in gills with increasing concentrations $\left(7-116 \mathrm{mg} \times \mathrm{L}^{-1}\right)$ and duration [73]. GST activity was

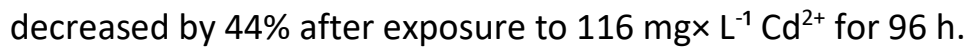

In mice liver GST showed a cadmium (up to $2.5 \mathrm{mg} \times \mathrm{L}^{-1} \mathrm{CdCl}_{2}$ ) -induced, duration (up to 7 alternate days) 220 dependent depression of conjugating capacity (35\%) [74]. This was correlated with elevated hepatic lipid peroxidation (102\%) and chromosomal aberrations (30\%). $\mathrm{CdCl}_{2}\left(4 \mathrm{mg} \times \mathrm{kg}^{-1}\right)$ also caused organ specific reduction of GST activity in heart (53\%) and renal (45\%) tissues of mice upon 6 or 3 days [75]. Concomitant 
accumulation of $\mathrm{Cd}$ in these tissues increased lipid peroxidation products and protein carbonyl contents, as well as decreased activities of other antioxidant enzymes. Murine hepatocytes, treated with $800 \mu \mathrm{M} \mathrm{CdCl}_{2}$ 225 for $3 \mathrm{~h}$ showed reduced GST activity associated with significant reduction of cell viability, increased levels of lipid peroxidation products and oxidized glutathione [76].

Tin

Organotin compounds such as tributyltin (TBT), triphenyltin (TPT) and dibutyltin (DBT), are extensively used as plastic stabilizers, wood preservatives and antifouling agents in paints. Due to their widespread use, high

230 amounts of butyltins have polluted the environment causing harmful toxic effects. Fishes are suitable organisms to evaluate the effect of such contaminants in aquatic ecosystems [77]. Organotins strongly inhibit GST activities in marine fish liver and kidney cytosol showing a 10 (liver) to 100 (kidney) times higher inhibition compared to inorganic tin [78]. This highlights the fact that inhibition depends on the chemical species. IC $\mathrm{C}_{50}$ values for hepatic GST ranged between 7.4-18 $\mu \mathrm{M}$ for Siganus canaliculatus (Rabbitfish), and 235 between 17-45 $\mu \mathrm{M}$ for Sparus sarba (Arabian seabream). The order of inhibitory potency was TBT > TPT > DBT; reversible inhibition was observed in all cases. Several times lower $\mathrm{IC}_{50}$ values have been recorded for kidney GST $(0.92-4 \mu \mathrm{M})$ indicating significantly higher sensitivity of renal isoenzymes to organotins. The results were consistent with previous in vitro competitive and reversible inhibition of rat liver GSTs by TBT and TPT [79]. Organotin compounds are a special case when studying GST inhibition as they represent metals 240 and organic xenobiotics in the same time. All studies proposed an inhibitory effect via a direct binding of the organotins to the active site of GST. Recent in vivo studies on TBT towards hepatic GST in Arctic charr (Salvelinus alpinus, $0.3 \mathrm{mg} \times \mathrm{kg}^{-1}$, at long-term exposure) confirmed the potent inhibitory effect but discussed also the possibility that organotins may compete with the detoxification of other organic xenobiotics for binding to GST and GSH [80].

\section{Mercury}

Mercury is present in the environment as several different chemical species showing a range of toxicological properties. These chemical forms can be classified as elemental $\left(\mathrm{Hg}^{0}\right)$, inorganic (e.g. $\left.\mathrm{Hg}^{2+}\right)$, and organic mercury, mainly alkyl mercury such as methyl mercury (MeHg). Goodrich and Basu [81] proved the influence of mercury among many other metals to genetically engineered GST allozymes. All allozymes were inhibited 250 strongly by $\mathrm{Hg}^{2+}$ (but also MeHg and selenium) (Tab.1). In a comprehensive in vitro study Sen and Semiz [82] investigated the effects of mercury and other toxic metals on cytosolic liver GST activities in the fish leaping mullet (Liza saliens). Both CDNB- and EA-GST were mainly inhibited by $\mathrm{Hg}^{2+}$ (CDNB-GST 70\% and EA-GST 86\%, resp.), but also by $\mathrm{Sb}^{2+}(69 \%$ and $78 \%)$, and $\mathrm{Cd}^{2+}(65 \%$ and $69 \%)$. Other tested metals $\mathrm{Cu}^{2+}, \mathrm{Zn}^{2+}, \mathrm{Co}^{2+}, \mathrm{Fe}^{3+}$, and $\mathrm{Fe}^{2+}$ exhibited more moderate effects (41-61\%). The fail of fully reactivation by GSH pointed to inhibition

255 mechanisms other than simple binding to SH-groups by toxic metals. In a recent study of Gunderson et al. [83] in the signal crayfish Pacifastacus leniusculus a similar decrease of the GST activity in hepatopancreas cytosol was observed under $\mathrm{Hg}^{2+}$ exposition at concentrations comparable to previous studies.

\section{Lead}

A continuous, low-level exposure of the freshwater crayfish Astacus astacus to lead $\left(20 \mu \mathrm{g} \times \mathrm{L}^{-1}\right)$ resulted in 260 strong decrease of GST activity in gills and digestive gland [72]. Accordingly, increased metal accumulation and severe structural impairment in these organs were observed. Thus, a chronic low-level metal stress may have a biological impact as great as short-term acute dose insults in aquatic ecosystems. Long term low-level lead exposure ( $0.1 \%$ in drinking water) of rats has been reported to profoundly impair phase I and phase II metabolising enzyme activity in the lenticular system of the animals. A very pronounced decrease (up to $55 \%$ 265 inhibition) was noticed in GST activity [84].

$\mathrm{Cd}^{2+}$ and $\mathrm{Pb}^{2+}$ have been shown to be potent inhibitors (by more than $50 \%$ at $100 \mu \mathrm{M}$ ) of pulmonary GST in rabbit lung cytosol [85]. Since GST and other detoxifying enzymes were found to be extremely poor in lung, in vitro enzyme assays are suitable tools to indicate pulmonary toxicities. 
GST inhibition in plants

270 Trace elements such as $\mathrm{Cu}, \mathrm{Zn}, \mathrm{Mn}, \mathrm{Fe}, \mathrm{Mo}$ and $\mathrm{Ni}$ are essential in small amounts for plant metabolism while higher concentrations can cause severe toxic effects [86]. Only few studies investigated the inhibition of GST activity in plants by metals such as $\mathrm{Cu}, \mathrm{Zn}, \mathrm{Cd}, \mathrm{As}, \mathrm{Pb}$, and Ni. Recently, Kumar and Trivedi [16] gave an overview regarding the role of GST for arsenic detoxification in plants.

Copper

275 Due to its redox activity $\left(\mathrm{Cu}^{+}, \mathrm{Cu}^{2+}\right)$ copper is of high significance for plants (respiratory chain: cytochrome oxidase, photosynthesis: plastocyanine). On the other hand, copper induce reactive oxygen species (ROS) by autoxidation and Fenton [87]. Ahsam et al. [88] did a general study of $\mathrm{Cu}^{2+}$ influence in rice (Oryza sativa) germination. During proteomic research in the first 4 days of germination, GST (identified by peptide-mass fingerprinting) showed a slightly decrease upon $\mathrm{CuSO}_{4}$ exposure $(1.5 \mathrm{mM}, 4 \mathrm{~d})$. Unfortunately the authors

280 did not assay enzyme activities. However, in a recent study Li et al. [89] measured the GST activity in roots of two varieties of Oryza sativa seedlings. In the Cu sensitive variety GST activity decreased by about $52 \%$ after 3 days $\mathrm{Cu}$ exposure $(8 \mu \mathrm{M})$ while the $\mathrm{Cu}$ tolerant variety showed only a GST activity decrease of $30 \%$. In duckweed (Lemna minor) GST activity was inhibited time- and concentration-dependently by $\mathrm{CuSO}_{4}$ [90]. For example, low Cu exposure $(0.25 \mu \mathrm{M}$ to $0.5 \mu \mathrm{M})$ lad to a stimulation (114.4\% to $125 \%)$ of GST as a consequence of $\mathrm{CuSO}_{4}$ addition. While higher $\mathrm{Cu}$ content $(2 \mu \mathrm{M})$ reduced GST activity (60\% of the control level).

Zinc

Zinc is typically the second (after iron) most abundant transition metal in plants [91]. In poplar lines different effects of $\mathrm{ZnSO}_{4}$ for GST activity were measured [92]. Leaf disks of 2 hybrids (Populus nigra (N-SL clone), $P$. canescens ( $P$. termula $\times P$. alba)) and 2 transgenic ( $P$. canescens) clones, overexpressing E. coli $\gamma$-ECS (11ggs: cytosol, 6Lgl: chloroplast)) were exposed to $\mathrm{Zn}\left(10^{-5}-10^{-1} \mathrm{M}, 21\right.$ days). In clone 11ggs GST activity was consistently lowered by $10^{-5}-10^{-1} \mathrm{M} \mathrm{ZnSO}_{4}$. In both hybrids GSTs were inhibited at high (cytotoxic) $\mathrm{Zn}^{2+}$ concentrations $\left(10^{-2}\right.$ and $\left.10^{-1} \mathrm{M}\right)$.

\section{Cadmium, arsenic, lead and nickel}

Cadmium which chemically is similar to zinc, generally causes toxic effects in plant species. Interest in Cd tolerance mechanisms $[93,94]$ is often driven by potential applications in phytoremediation $[95,96]$. While GST activities in 25 day old hydroponic cultures of Indian mustard (Brassica juncea L. cv. Vitasso) after $\mathrm{Cd}^{2+}$ ( 5 days, $10 \mu \mathrm{M}$ ) which is environmentally relevant, were not influenced, higher metal concentrations decreased GST activity significantly to $61.3 \%(30 \mu \mathrm{M}), 82.4 \%(50 \mu \mathrm{M})$ and $66.4 \%(100 \mu \mathrm{M})$ [97]. Interestingly no continuous decrease was observed. A 10 days exposure of Cd ( $40 \mathrm{mg} \mathrm{L-1)}$ to rice (Oryza sativa) showed a significant inhibition of GST activity by $63 \%$ in rice roots in contrast to a minimal increase in shoots [98].

Typha latifolia is some of the potent wetland plants for phytoremediation. It is used in constructed wetlands, an alternative to traditional industrial wastewater treatment [99]. After $72 \mathrm{~h}$ exposures of Typha latifolia either to $\mathrm{Pb}$, arsenite, or Cd showed remarkable GST inhibitions in leaves [95].

Arsenic and lead are taken up by plants from the soil, water or air. Spruce cell culture (Picea abies L.Karst.) were exposed for $16 \mathrm{~h}$ to $50-500 \mu \mathrm{M} \mathrm{CdSO}_{4}, 1.5-80 \mu \mathrm{M} \mathrm{Na}_{2} \mathrm{HAsO}_{4}$ and 50-400 $\mu \mathrm{M} \mathrm{PbCl}_{2}$ [100]. To distinguish between different GST isoforms 4 different standard substrates for activity assay were used. Only assays with 1,2-epoxy-3-(p-nitrophenoxy)-propane (EPNP) as substrate showed remarkable inhibition effects (60\%) caused by cadmium. Under lead exposure the same effect was observed with a slightly higher residual enzyme activity (56\%). Arsenic inhibited EPNP conjugation continuous with higher concentration. GST was assayed in horseradish (Armoracia rusticana L.) hairy root culture, incubated for $6 \mathrm{~h}$ with 0.1 and $0.5 \mathrm{mM}$ $\mathrm{Cd}^{2+}, \mathrm{Ni}^{2+}$ and $\mathrm{Pb}^{2+}$ using 1-chloro-2,4-dinitrobenzene (CDNB) and 1,2-dichloro-4-nitrobenzene (DCNB) in order to detect different GST isoforms [101]. While GST activity with CDNB was not influenced, assays with DCNB showed decreasing activity levels in a metal dependent manner in the range of $35 \%$ (for $\mathrm{Ni}^{2+}$ ) to $63 \%$ $\left(\right.$ for $\left.\mathrm{Cd}^{2+}\right)$. 
Metals represent a major ecological concern because they can accumulate in organisms in the food web and finally, they can be a threat to human health. Impact of metals to aquatic and terrestrial ecosystems at sublethal contaminant concentrations can cause biological responses of the glutathione antioxidative network including glutathione transferases in organisms living in polluted habitats. On cellular level, metals are able to inhibit different intracellular processes such as enzyme activities. Inhibition of GSTs in animals and plants represents an early warning biomarker indicating a sensitive physiological response of organism to metals. In this context the measurement of GST activity is an important tool. In most studies, metals decreased GST activity supporting the fact that GST is part of the cellular antioxidant defense system where it is serving as bifunctional enzyme: GST and as glutathione peroxidase, too. Furthermore, animal and plant glutathione transferases are involved in detoxification of xenobiotics and endobiotic metabolites. Therefore, interferences with the functionality of GSTs caused by toxic metals or imbalanced essential biometals may have unpredictable toxicological consequences for the organisms. However, it is difficult to make a general assessment of the level at which natural exposure, dietary supplementation, over-nutritional dietary supplementation or poisoning will show effects.

330 When reviewing the literature on animal studies it can be concluded that the majority of articles are dealing with organisms living in aquatic ecosystems. Here, fishes are of particular interest because in contaminated aquatic environments they are in direct contact with toxic substances in contrast to terrestrial animals which have a rather selective contact with toxic substances in a contaminated site. Fish gills are organs and tissue which are primarily affected because they provide a large surface area in contact with contaminants dissolved in water. Gill cells respond rapidly to metals and thus gills are major targets for measurement of acute toxicity via GST activity. Moreover, some fish species such as signal crayfish are living in relatively small habitats; therefore they can serve as good bioindicators for specific exposed areas.

Rather few studies have investigated the impact of metals to GST activity in plants although plants as sessile organisms represent suitable bioindicators for specific contaminated sites as well as for long-term

340 observation of pollution. With respect to metal polluted aquatic ecosystems only one plant study has been published so far. It investigated the aquatic macrophyte Typha latifolia which represents a common wetland plant used in some cases for phytoremediation in constructed wetlands for sustainable waste water treatment. This plant can accumulate metals, however, after long-term exposure a decrease of GST activity was observed. This particular case demonstrates that there is a lack of studies in this field. In future, more 345 investigations on GST activity in plants exposed to toxic metal in aquatic as well as in terrestrial ecosystems would be desirable in order to fill this gap of knowledge.

\section{Acknowledgements}

This work was supported by the bilateral (German-French) DAAD - Campus France program PROCOPE funded by the German 'Bundesministerium für Bildung und Forschung (BMBF)', the French 'Ministère des Affaires

350 étrangères et du développement International (MAEDI)' and 'Ministère de l'Education nationale, de l'Enseignement supérieur et de la Recherche (MENESR)'.

\section{Conflict of interest}

The authors declare no conflict of interests. 


\section{Figure legends}

355 Figure 1: General scheme of the glutathione transferase (GST) catalysed detoxification of organic xenobiotics and endobiotic metabolites and its impairment by metals at toxic concentration, either by direct inhibition of enzyme activity* or indirectly by decreasing the concentration of the GST substrate glutathione (GSH) via changing the GSH/GSSG equilibrium**.

360 Figure 2: A graphical overview of the different classes of glutathione transferase (modified from Kumar and Trivedi [16], Copyright @ 2018 Kumar and Trivedi, doi: 10.3389/fpls.2018.00751).

Figure 3: Measurement of the GST activity and its inhibition by metals by using the model xenobiotic CDNB (1-chloro-2,4-dinitrobenzene). GST catalyses the reaction of reduced GSH with CDNB via a nucleophilic 365 aromatic substitution, the absorbance of the resulting GS-conjugate measured at $340 \mathrm{~nm}$ indicates the GST activity. 
Figures

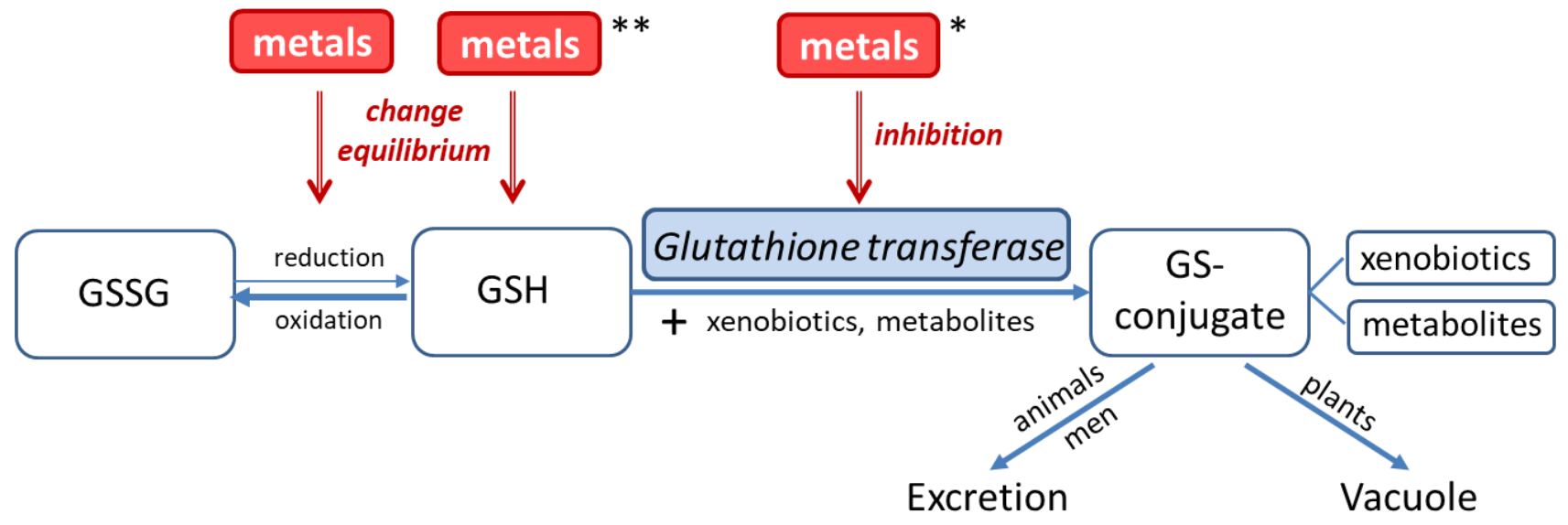

Figure 1 


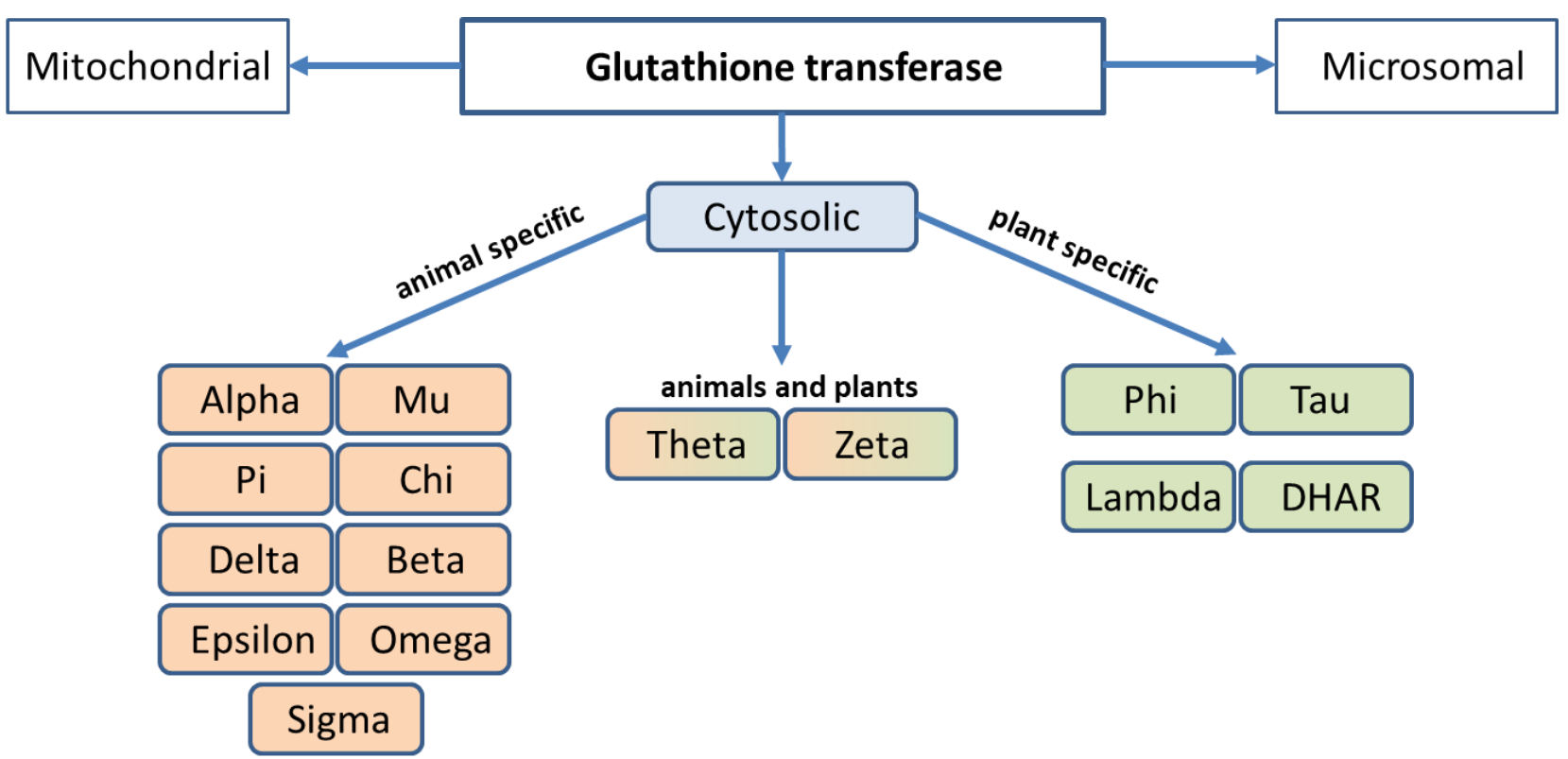

Figure 2 


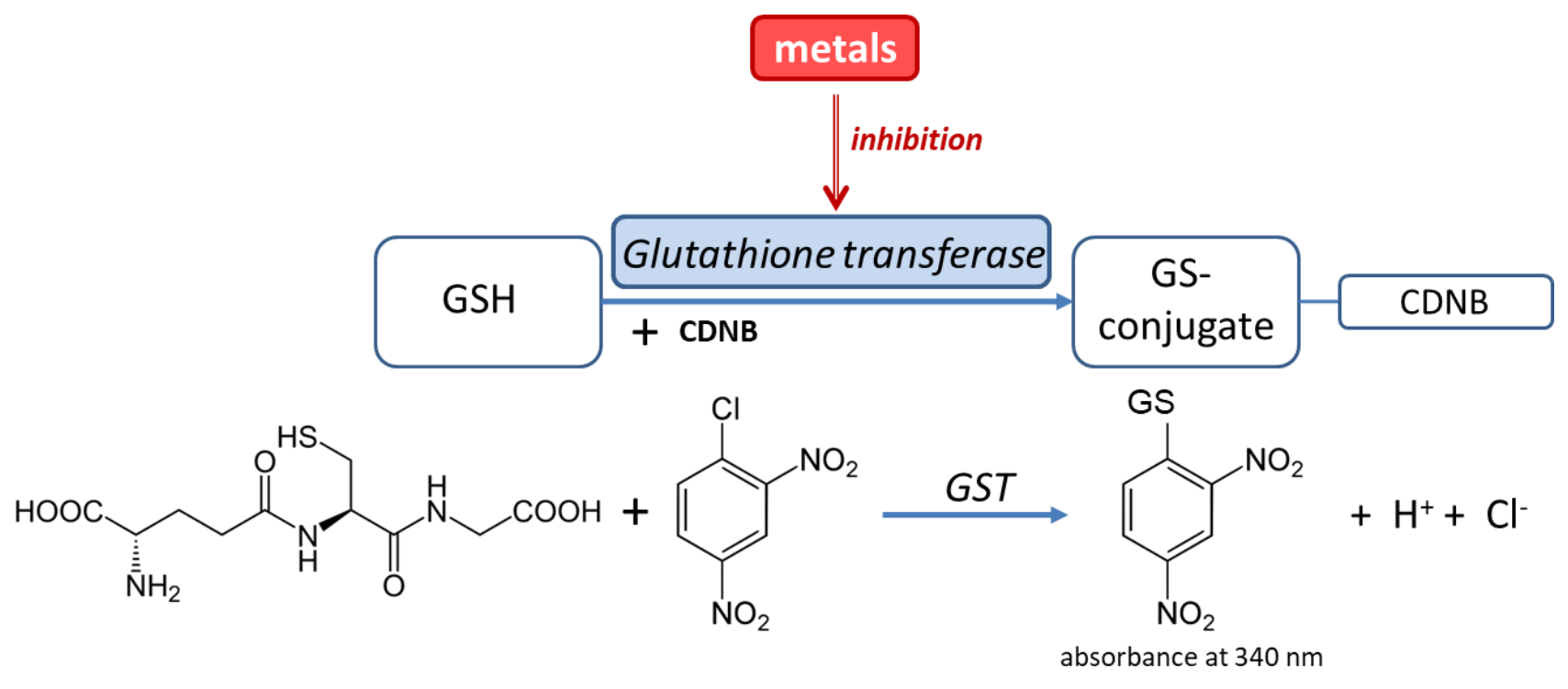

Figure 3 
Table 1. In vitro and in vivo inhibitory effects of metals on cytosolic GST* activity

\begin{tabular}{|c|c|c|c|c|c|c|}
\hline $\begin{array}{l}\text { Metal or } \\
\text { metal } \\
\text { compound }\end{array}$ & Exposure & $\begin{array}{l}\text { Acceptor } \\
\text { substrate }\end{array}$ & Enzyme source & Inhibition & $\begin{array}{r}\text { IC50 } \\
(\mu M)\end{array}$ & Ref. \\
\hline \multicolumn{7}{|l|}{ Animals } \\
\hline $\mathrm{Al}^{3+}$ & $100 \mathrm{mg} / \mathrm{kg}$ & CDNB & male Sprague Dawley rats & $68 \%$ & & [43] \\
\hline $\mathrm{Al}^{3+}$ & $172.5 \mathrm{mg} / \mathrm{kg}$ & CDNB & female Wistar rats & $24 \%$ & & [44] \\
\hline $\mathrm{Cr}^{6+}$ & $10 \mathrm{mg} / \mathrm{L}$ & CDNB & Frogs (Rana ridibunda) & $58 \%$ & & [50] \\
\hline $\mathrm{Cu}^{2+}$ & & CDNB & Rat liver cytosol & \multicolumn{2}{|c|}{$\begin{array}{r}0.23 \\
\text { in the presence of } \\
1 \mathrm{mM} \text { ascorbate }\end{array}$} & [55] \\
\hline $\mathrm{Cu}^{2+}$ & $100 \mu \mathrm{M}$ & CDNB & Mullet (Liza saliens) liver cytosol & $61 \%$ & & [82] \\
\hline $\mathrm{Cu}^{2+}$ & & EA & & $51 \%$ & & [82] \\
\hline $\mathrm{Cu}^{2+}$ & $\begin{array}{r}100-800 \\
\mathrm{mg} / \mathrm{kg}\end{array}$ & CDNB & $\begin{array}{l}\text { Protaetia brevitarsis Lewis } \\
\text { larvae }\end{array}$ & $37 \%-45 \%$ & & [54] \\
\hline $\mathrm{As}^{3+}\left(\mathrm{NaAsO}_{2}\right)$ & $10 \mathrm{mg} / \mathrm{kg}$ & CDNB & Swiss mice & $53 \%$ & & [56] \\
\hline $\mathrm{As}^{3+}\left(\mathrm{As}_{2} \mathrm{O}_{3}\right)$ & $500 \mu \mathrm{g} / \mathrm{L}$ & CDNB & Worm (Laeonereis acuta) & $48 \%$ & & [59] \\
\hline $\mathrm{Sb}^{3+}$ & $100 \mu \mathrm{M}$ & CDNB & Mullet (Liza saliens) liver cytosol & $69 \%$ & & [82] \\
\hline $\mathrm{Sb}^{3+}$ & & EA & & $69 \%$ & & [82] \\
\hline $\mathrm{SeO}_{3}{ }^{2-}$ & $100 \mu \mathrm{g} / \mathrm{L}$ & CDNB & $\begin{array}{l}\text { Tilapia fish (Oreochromis } \\
\text { mossambicus) }\end{array}$ & $20 \%$ & & [62] \\
\hline $\mathrm{Ag}^{+}$ & $15 \mu \mathrm{M}$ & CDNB & $\begin{array}{l}\text { Van Lake fish (Chalcalburnus } \\
\text { tarichii) }\end{array}$ & & 11 & [65] \\
\hline $\mathrm{Ag}^{+}$ & $60 \mu \mathrm{M}$ & CDNB & $\begin{array}{l}\text { Erythrocytes (rainbow trout, } \\
\text { Oncorhynchus mykiss) }\end{array}$ & & 35 & [64] \\
\hline $\mathrm{Ag}^{+}$ & $2 \mu \mathrm{M}$ & CDNB & Turkey liver & & 0.4 & [67] \\
\hline $\mathrm{Cd}^{2+}$ & $100 \mu \mathrm{M}$ & CDNB & Mullet (Liza saliens) liver cytosol & $65 \%$ & & [82] \\
\hline $\mathrm{Cd}^{2+}$ & & EA & & $78 \%$ & & [82] \\
\hline $\mathrm{Cd}^{2+}$ & $100 \mu \mathrm{M}$ & CDNB & $\begin{array}{l}\text { Rabbit (Oryctolagus cuniculus) } \\
\text { lung cytosol }\end{array}$ & $53 \%$ & & [85] \\
\hline $\mathrm{Cd}^{2+}$ & $2.5 \mathrm{mg} / \mathrm{kg}$ & CDNB & Balb/C mice & $35 \%$ & & [74] \\
\hline $\mathrm{Cd}^{2+}$ & $1 \mathrm{mg} / \mathrm{kg}$ & CDNB & Plaice (Pleuronectes platessa) & $90 \%$ & & [102] \\
\hline $\mathrm{Cd}^{2+}$ & $800 \mu \mathrm{M}$ & CDNB & Murine hepatocytes & $41 \%$ & & [76] \\
\hline $\mathrm{Cd}^{2+}$ & $116 \mathrm{mg} / \mathrm{L}$ & CDNB & $\begin{array}{l}\text { Freshwater crab (S. } \\
\text { yangtsekiense) }\end{array}$ & $44 \%$ & & [103] \\
\hline Tributyltin & & CDNB & $\begin{array}{l}\text { Rabbitfish }^{a} \text { (Siganus } \\
\text { canaliculatus) }\end{array}$ & & 0.92 & [78] \\
\hline Tributyltin & & CDNB & Seabream ${ }^{a}$ (Sparus sarba) & & 3.5 & [78] \\
\hline Tributyltin & $0.3 \mathrm{mg} / \mathrm{kg}$ & CDNB & Arctic charr (Salvelinus alpinus) & $70 \%$ & & [80] \\
\hline Dibutyltin & & CDNB & $\begin{array}{l}\text { Rabbitfish }{ }^{\text {a Siganus }} \\
\text { canaliculatus) }\end{array}$ & & 3.2 & [78] \\
\hline Triphenyltin & & CDNB & $\begin{array}{l}\text { Rabbitfisha (Siganus } \\
\text { canaliculatus) }\end{array}$ & & 4 & [78] \\
\hline Triphenyltin & & & Seabream ${ }^{a}$ (Sparus sarba) & & 1.8 & [78] \\
\hline $\mathrm{Hg}^{2+}$ & $100 \mu \mathrm{M}$ & CDNB & Mullet (Liza saliens) liver cytosol & $70 \%$ & & [82] \\
\hline $\mathrm{Hg}^{2+}$ & & EA & & $86 \%$ & & [82] \\
\hline
\end{tabular}




\begin{tabular}{|c|c|c|c|c|c|c|}
\hline $\begin{array}{l}\text { Metal or } \\
\text { metal } \\
\text { compound }\end{array}$ & Exposure & $\begin{array}{l}\text { Acceptor } \\
\text { substrate }\end{array}$ & Enzyme source & Inhibition & $\begin{array}{l}\text { IC50 } \\
(\mu M)\end{array}$ & Ref. \\
\hline $\mathrm{Hg}^{2+}$ & $0.9 \mu \mathrm{g} / \mathrm{kg}$ & CDNB & $\begin{array}{l}\text { Signal crayfish (Pacifastacus } \\
\text { leniusculus) hepatopancreas } \\
\text { cytosol }\end{array}$ & $70 \%$ & & [83] \\
\hline $\mathrm{Pb}^{2+}$ & $20 \mu \mathrm{g} / \mathrm{L}$ & CDNB & $\begin{array}{l}\text { Freshwater crayfish (Astacus } \\
\text { astacus) }\end{array}$ & $\begin{array}{r}77 \% \\
\text { in gills } \\
44 \% \\
\text { in digestive } \\
\text { gland }\end{array}$ & & [72] \\
\hline $\mathrm{Pb}^{2+}$ & $100 \mu \mathrm{M}$ & CDNB & $\begin{array}{l}\text { Rabbit (Japanese White) lung } \\
\text { cytosol }\end{array}$ & $74 \%$ & & [85] \\
\hline $\mathrm{Pb}^{2+}$ & $0.1 \%^{b}$ & CDNB & Sprague-Dawley rats & $55 \%$ & & [84] \\
\hline \multicolumn{7}{|l|}{ Plants } \\
\hline $\mathrm{Cu}^{2+}$ & $1.5 \mathrm{mM}$ & & Rice (Oryza sativa) seedlings & & & [88] \\
\hline $\mathrm{Cu}^{2+}$ & $8 \mu \mathrm{M}$ & CDNB & $\begin{array}{l}\text { Rice (Oryza sativa) seedlings, } \\
\text { roots, Cu sensitive variety }\end{array}$ & $\sim 52 \%$ & & [89] \\
\hline $\mathrm{Cu}^{2+}$ & $5 \mu \mathrm{M}$ & CDNB & Duckweed (Lemna minor) & $\sim 40 \%$ & & [90] \\
\hline $\mathrm{Zn}^{2+}$ & $100 \mathrm{mM}$ & CDNB & Poplar (Populus) & & & [92] \\
\hline $\mathrm{Cd}^{2+}$ & $30 \mu \mathrm{M}$ & CDNB & $\begin{array}{l}\text { Indian mustard (Brassica } \\
\text { juncea) }\end{array}$ & $40 \%$ & & [97] \\
\hline $\mathrm{Cd}^{2+}$ & $50 \mu \mathrm{M}$ & EPNP & Spruce (Picea) & $60 \%$ & & [100] \\
\hline $\mathrm{Cd}^{2+}$ & $100 \mu \mathrm{M}$ & DCNB & $\begin{array}{l}\text { Horseradish (Armoracia } \\
\text { rusticana) }\end{array}$ & $55 \%$ & & [101] \\
\hline $\mathrm{Cd}^{2+}$ & $50 \mu \mathrm{M}$ & CDNB & Typha latifolia & $50 \%$ & & [95] \\
\hline $\mathrm{AsO}_{4}{ }^{2-}$ & $80 \mu \mathrm{M}$ & EPNP & Spruce (Picea) & $67 \%$ & & [100] \\
\hline $\mathrm{AsO}_{4}{ }^{2-}$ & $50 \mu \mathrm{M}$ & CDNB & Typha latifolia & $80 \%$ & & [95] \\
\hline $\mathrm{Pb}^{2+}$ & $100 \mu \mathrm{M}$ & DCNB & $\begin{array}{l}\text { Horseradish (Armoracia } \\
\text { rusticana) }\end{array}$ & $42 \%$ & & [101] \\
\hline $\mathrm{Pb}^{2+}$ & $50 \mu \mathrm{M}$ & EPNP & Spruce (Picea) & $45 \%$ & & [100] \\
\hline $\mathrm{Pb}^{2+}$ & $50 \mu \mathrm{M}$ & CDNB & Typha latifolia & $80 \%$ & & [95] \\
\hline $\mathrm{Ni}^{2+}$ & $500 \mu \mathrm{M}$ & DCNB & $\begin{array}{l}\text { Horseradish (Armoracia } \\
\text { rusticana) }\end{array}$ & $37 \%$ & & [101] \\
\hline
\end{tabular}


${ }^{*}$ Membrane-associated glutathione S-transferases not involved in intracellular detoxification processes were not considered here. These GSTs are more likely to be involved in special developmental processes (e.g. heat shock in stationary phase and ability to grow at $39^{\circ} \mathrm{C}$, [104]. Membrane bound microsomal GSTs are involved in the endogenous metabolism of leukotrienes and prostaglandins [105].

aPMS of kidney homogenate

EPNP $=1,2$-epox-y-3-(p-nitrophenoxy)-propane

DCNB = 1,2-dichloro-4-nitrobenzene

CDNB $=$ 1-chloro-2,4-dinitrobenzene

$390 \quad E A=$ ethacrynic acid 


\section{References}

[1] R.G. Garrett, Natural sources of metals to the environment, Hum. Ecol. Risk Assess. 6 (2000) 945-963.

395 [2] J.M. Benoit, C.C. Gilmour, A. Heyes, R.P. Mason, C.L. Miller, Geochemical and biological controls over methylmercury production and degradation in aquatic ecosystems, in Biogeochemistry of Environmentally Important Trace Elements, ed. by Y. Cai and O.C. Braids, Washington: Amer Chemical Soc, (2003), pp. 262-297.

[3] O. Bruneel, A. Volant, S. Gallien, B. Chaumande, C. Casiot, C. Carapito, A. Bardil, G. Morin, 400

[4] N.A. Anjum, I. Ahmad, I. Mohmood, M. Pacheco, A.C. Duarte, E. Pereira, S. Umar, A. Elbaz-Poulichet, F. Arsene-Ploetze, Characterization of the Active Bacterial Community Involved in Natural Attenuation Processes in Arsenic-Rich Creek Sediments, Microb. Ecol. 61 (2011) 793-810.

Ahmad, N.A. Khan, M. Iqbal, M.N.V. Prasad, Modulation of glutathione and its related enzymes in plants' responses to toxic metals and metalloids-A review, Environ. Exp. Bot. 75 (2012) 307-324.

[5] E.V. Kalinina, N.N. Chernov, M.D. Novichkova, Role of Glutathione, Glutathione Transferase, and Glutaredoxin in Regulation of Redox-Dependent Processes, Biochemistry

[6] F.M. Rubino, Toxicity of Glutathione-Binding Metals: A Review of Targets and Mechanisms, Toxics 3 (2015) 20-62.

[7] G.J. Krauss, D. Schlosser, Sensing of Pollutant Effects and Bioremediation, in Ecological Biochemistry: Environmental and Interspecies Interactions, ed. by G.J. Krauss and D.H. Niess, Weinheim: Wiley-VCH Verlag GmbH \& Co. KGaA, (2015), pp. 333-340.

[8] S. Kurwadkar, Occurrence and distribution of organic and inorganic pollutants in groundwater, Water Environment Research. doi:10.1002/wer.1166 (2019).

[9] N. Allocati, L. Federici, M. Masulli, C. Di Ilio, Glutathione transferases in bacteria, Febs J. 276 (2009) 58-75.

420 [10] N. Allocati, L. Federici, M. Masulli, C. Di Ilio, Distribution of glutathione transferases in Gram-positive bacteria and Archaea, Biochimie 94 (2012) 588-596.

[11] D. Sheehan, G. Meade, V.M. Foley, C.A. Dowd, Structure, function and evolution of glutathione transferases: implications for classification of non-mammalian members of an ancient enzyme superfamily, Biochem. J. 360 (2001) 1-16.

425 [12] D. Dourado, P.A. Fernandes, M.J. Ramos, Mammalian cytosolic glutathione transferases, Curr. Protein Pept. Sci. 9 (2008) 325-337.

[13] P. Jancova, P. Anzenbacher, E. Anzenbacherova, Phase II drug metabolizing enzymes, Biomed. Pap-Olomouc 154 (2010) 103-116.

[14] D.P. Dixon, M. Skipsey, R. Edwards, Roles for glutathione transferases in plant secondary

[15] I. Cummins, D.P. Dixon, S. Freitag-Pohl, M. Skipsey, R. Edwards, Multiple roles for plant glutathione transferases in xenobiotic detoxification, Drug Metab. Rev. 43 (2011) 266-280.

[16] S. Kumar, P.K. Trivedi, Glutathione S-Transferases: Role in Combating Abiotic Stresses Including Arsenic Detoxification in Plants, Front. Plant Sci. 9 (2018).

435 [17] C. Frova, Glutathione transferases in the genomics era: New insights and perspectives, Biomol. Eng. 23 (2006) 149-169.

[18] G.E. Edwards, V.R. Franceschi, M.S.B. Ku, E.V. Voznesenskaya, V.I. Pyankov, C.S. Andreo, Compartmentation of photosynthesis in cells and tissues of C-4 plants, J. Exp. Bot. 52 (2001) 577-590.

440 [19] D.P. Dixon, A. Lapthorn, R. Edwards, Plant glutathione transferases, Genome Biol. 3 (2002) Article Number: 3004.3001 
[20] Y.H. Chi, Y. Cheng, J. Vanitha, N. Kumar, R. Ramamoorthy, S. Ramachandran, S.Y. Jiang, Expansion Mechanisms and Functional Divergence of the Glutathione S-Transferase Family in Sorghum and Other Higher Plants, DNA Res. 18 (2011) 1-16.

[21] J.D. Hayes, L.I. McLellan, P.K. Stockman, J. Chalmers, G.J. Beckett, Glutathione Stransferases in man: the relationship between rat and human enzymes, Biochem. Soc. Trans. 15 (1987) 721-725.

[22] K.D. Tew, Glutathione-associated Enzymes in Anticancer Drug Resistance, Cancer Res. 54 (1994) 4313-4320.

[23] D.M. Townsend, K.D. Tew, The role of glutathione-S-transferase in anti-cancer drug resistance, Oncogene 22 (2003) 7369-7375.

[24] A.S. Johansson, B. Mannervik, Human glutathione transferase A3-3, a highly efficient catalyst of double-bond isomerization in the biosynthetic pathway of steroid hormones, $\mathrm{J}$. Biol. Chem. 276 (2001) 33061-33065.

[25] P.G. Board, D. Menon, Glutathione transferases, regulators of cellular metabolism and physiology, Biochim. Biophys. Acta-Gen. Subj. 1830 (2013) 3267-3288.

[26] I. Nianiou-Obeidat, P. Madesis, C. Kissoudis, G. Voulgari, E. Chronopoulou, A. Tsaftaris, N.E. Labrou, Plant glutathione transferase-mediated stress tolerance: functions and biotechnological applications, Plant Cell Reports 36 (2017) 791-805.

[27] K.D. Tew, Y. Manevich, C. Grek, Y. Xiong, J. Uys, D.M. Townsend, The role of glutathione S-transferase $\mathrm{P}$ in signaling pathways and S-glutathionylation in cancer, Free Radic. Biol. Med. 51 (2011) 299-313.

[28] I. Hubatsch, M. Ridderstrom, B. Mannervik, Human glutathione transferase A4-4: an Alpha class enzyme with high catalytic efficiency in the conjugation of 4-hydroxynonenal and other genotoxic products of lipid peroxidation, Biochem. J. 330 (1998) 175-179.

[29] R. Sharma, D. Brown, S. Awasthi, Y.S. Yang, A. Sharma, B. Patrick, M.K. Saini, S.P. Singh, P. Zimniak, S.V. Singh, Y.C. Awasthi, Transfection with 4-hydroxynonenal-metabolizing glutathione S-transferase isozymes leads to phenotypic transformation and immortalization of adherent cells, Eur. J. Biochem. 271 (2004) 1690-1701.

[30] E. Tipping, B. Ketterer, P. Koskelo, Binding of porphyrins by ligandin, Biochem. J. 169 (1978) 509-516.

[31] U.H. Danielson, B. Mannervik, Kinetic independence of the subunits of cytosolic glutathione transferase from the rat, Biochem. J. 231 (1985) 263-267.

[32] L.A. Mueller, C.D. Goodman, R.A. Silady, V. Walbot, AN9, a petunia glutathione Stransferase required for anthocyanin sequestration, is a flavonoid-binding protein, Plant Physiol. 123 (2000) 1561-1570.

[33] D.P. Dixon, R. Edwards, Selective Binding of Glutathione Conjugates of Fatty Acid Derivatives by Plant Glutathione Transferases, J. Biol. Chem. 284 (2009) 21249-21256.

[34] M. Hasanuzzaman, K. Nahar, T.I. Anee, M. Fujita, Glutathione in plants: biosynthesis and physiological role in environmental stress tolerance, Physiol. Mol. Biol. Plants 23 (2017) 249268.

[35] A. Galle, Z. Czekus, K. Bela, E. Horvath, A. Ordog, J. Csiszar, P. Poor, Plant Glutathione Transferases and Light, Front. Plant Sci. 9 (2019).

[36] G. Gullner, T. Komives, L. Kiraly, P. Schroder, Glutathione S-Transferase Enzymes in PlantPathogen Interactions, Front. Plant Sci. 9 (2018).

[37] M. Edalat, M.A.A. Persson, B. Mannervik, Selective recognition of peptide sequences by glutathione transferases: A possible mechanism for modulation of cellular stress-induced signaling pathways, Biol. Chem. 384 (2003) 645-651.

[38] Y.M. Liu, W. Min, Thioredoxin promotes ASK1 ubiquitination and degradation to inhibit ASK1-mediated apoptosis in a redox activity-independent manner, Circ.Res. 90 (2002) 12591266. 
[39] R. Monaco, F.K. Friedman, M.J. Hyde, J.M. Chen, S. Manolatus, V. Adler, Z. Ronai, W. Koslosky, M.R. Pincus, Identification of a glutathione-S-transferase effector domain for inhibition of jun kinase, by molecular dynamics, J. Protein Chem. 18 (1999) 859-866.

[40] P. Ruzza, A. Rosato, C.R. Rossi, M. Floreani, L. Quintieri, Glutathione Transferases as Targets for Cancer Therapy, Anti-Cancer Agents Med. Chem. 9 (2009) 763-777.

[41] A. Sau, F.P. Tregno, F. Valentino, G. Federici, A.M. Caccuri, Glutathione transferases and development of new principles to overcome drug resistance, Arch. Biochem. Biophys. 500 (2010) 116-122.

[42] W.H. Habig, M.J. Pabst, W.B. Jakoby, Glutathione S-Transferases - First Enzymatic Step in Mercapturic Acid Formation, J. Biol. Chem. 249 (1974) 7130-7139.

[43] N. Singla, D.K. Dhawan, Zinc modulates aluminium-induced oxidative stress and cellular injury in rat brain, Metallomics 6 (2014) 1941-1950.

[44] P. Sharma, Z.A. Shah, A. Kumar, F. Islam, K.P. Mishra, Role of combined administration of Tiron and glutathione against aluminum-induced oxidative stress in rat brain, J. Trace Elem. Med. Biol. 21 (2007) 63-70.

[45] F.M. El-Demerdash, Antioxidant effect of vitamin E and selenium on lipid peroxidation, enzyme activities and biochemical parameters in rats exposed to aluminium, J. Trace Elem. Med. Biol. 18 (2004) 113-121.

510 [46] W. Mertz, Chromium in human nutrition - a review, J. Nutr. 123 (1993) 626-633.

[47] J.B. Vincent, New Evidence against Chromium as an Essential Trace Element, The Journal of Nutrition 147 (2017) 2212-2219.

[48] L. Gerhardsson, S. Skerfving, Concepts on biological markers and biomonitoring for metal toxicity, in Toxicology of Metals, ed. by L. Chang, New York: Lewis Publishers, (1966), pp. 81-107.

[49] Toxicological Profile: Chromium, The Agency for Toxic Substances and Disease Registry (ATSDR), (2012).

[50] I. Kostaropoulos, D. Kalmanti, B. Theodoropoulou, N. Loumbourdis, Effects of exposure to a mixture of cadmium and chromium on detoxification enzyme (GST, P450-MO) activities in

[51] P.G. Georgopoulos, A. Roy, M.J. Yonone-Lioy, R.E. Opiekun, P.J. Lioy, Environmental copper: Its dynamics and human exposure issues, J. Toxicol. Env. Health, Part B. 4 (2001) 341-394.

[52] National_Research_Council, Copper in Drinking Water (2000), The National Academies Press, Washington, DC, https://doi.org/10.17226/19782.

[53] M. Arabi, M.A. Alaeddini, Metal-ion-mediated oxidative stress in the gill homogenate of rainbow trout (Oncorhynchus mykiss) - Antioxidant potential of manganese, selenium, and albumin, Biol. Trace Elem. Res. 108 (2005) 155-168.

[54] S.Z. Yin, G.D. Li, M.M. Liu, C.L. Wen, Y.Y. Zhao, Biochemical responses of the Protaetia brevitarsis Lewis larvae to subchronic copper exposure, Environ. Sci. Pollut. Res. 25 (2018) 18570-18578.

[55] M.E. Letelier, M. Martinez, V. Gonzalez-Lira, M. Faundez, P. Aracena-Parks, Inhibition of cytosolic glutathione S-transferase activity from rat liver by copper, Chem.-Biol. Interact. 164 (2006) 39-48.

535 [56] P. Manna, M. Sinha, P.C. Sil, Arsenic-induced oxidative myocardial injury: protective role of arjunolic acid, Arch. Toxicol. 82 (2008) 137-149.

[57] M. Sinha, P. Manna, P.C. Sil, Arjunolic acid attenuates arsenic-induced nephrotoxicity, Pathophysiology 15 (2008) 147-156.

[58] R.C. Lantz, B.J. Lynch, S. Boitano, G.S. Poplin, S. Littau, G. Tsaprailis, J.L. Burgess, 540 Pulmonary biomarkers based on alterations in protein expression after exposure to arsenic, Environ. Health Perspect. 115 (2007) 586-591. 
[59] J. Ventura-Lima, J.Z. Sandrini, M.F. Cravo, F.R. Piedras, T.B. Moraes, D. Fattorini, A. Notti, F. Regoli, L.A. Geracitano, L.F.F. Marins, J.M. Monserrat, Toxicological responses in Laeonereis acuta (annelida, polychaeta) after arsenic exposure, Environ. Int. 33 (2007) 559564.

[60] M.J. Tamas, Cellular and molecular mechanisms of antimony transport, toxicity and resistance, Environ. Chem. 13 (2016) 955-962.

[61] R. Poon, I. Chu, Effects of trivalent antimony on human erythrocyte glutathione-Stransferases, J. Biochem. Mol. Toxicol. 14 (2000) 169-176.

[62] N. Gobi, B. Vaseeharan, R. Rekha, S. Vijayakumar, C. Faggio, Bioaccumulation, cytotoxicity and oxidative stress of the acute exposure selenium in Oreochromis mossambicus, Ecotox. Environ. Safe. 162 (2018) 147-159.

[63] P. Kaur, S. Yousuf, M.A. Ansari, A. Siddiqui, A.S. Ahmad, F. Islam, Tellurium-induced dosedependent impairment of antioxidant status - Differential effects in cerebrum, cerebellum, and brainstem of mice, Biol. Trace Elem. Res. 94 (2003) 247-258.

[64] V. Comakli, M. Ciftci, O.I. Kufrevioglu, Effects of some metal ions on rainbow trout erythrocytes glutathione S-transferase enzyme: an in vitro study, J. Enzym. Inhib. Med. Chem. 28 (2013) 1261-1266.

[65] M. Aksoy, M.S. Ozaslan, O.I. Kufrevioglu, Purification of glutathione S-transferase from Van Lake fish (Chalcalburnus tarichii Pallas) muscle and investigation of some metal ions effect on enzyme activity, J. Enzym. Inhib. Med. Chem. 31 (2016) 546-550.

[66] M.S. Ozaslan, Y. Demir, O.I. Kufrevioglu, M. Ciftci, Some metals inhibit the glutathione Stransferase from Van Lake fish gills, J. Biochem. Mol. Toxicol. 31 (2017).

[67] E. Akkemik, P. Taser, A. Bayindir, H. Budak, M. Ciftci, Purification and characterization of glutathione S-transferase from turkey liver and inhibition effects of some metal ions on enzyme activity, Environ. Toxicol. Pharmacol. 34 (2012) 888-894.

[68] A.D. Maynard, R.J. Aitken, T. Butz, V. Colvin, K. Donaldson, G. Oberdörster, M.A. Philbert, J. Ryan, A. Seaton, V. Stone, S.S. Tinkle, L. Tran, N.J. Walker, D.B. Warheit, Safe handling of nanotechnology, Nature 444 (2006) 267-269.

[69] P.V. Asharani, Y.L. Wu, Z.Y. Gong, S. Valiyaveettil, Toxicity of silver nanoparticles in zebrafish models, Nanotechnology 19 (2008) 255102.

[70] P. Sillapawattana, M.C.H. Gruhlke, A. Schäffer, Effect of silver nanoparticles on the standard soil arthropod Folsomia candida (Collembola) and the eukaryote model organism Saccharomyces cerevisiae, Environmental Sciences Europe 28 (2016) 27.

575 [71] P.M.G. Nair, J. Choi, Identification, characterization and expression profiles of Chironomus riparius glutathione S-transferase (GST) genes in response to cadmium and silver nanoparticles exposure, Aquat. Toxicol. 101 (2011) 550-560.

[72] W. Meyer, M. Kretschmer, A. Hoffmann, G. Harisch, Biochemical and histochemical observations on effects of low-level heavy metal load (lead, cadmium) in different organ systems of the freshwater crayfish, Astacus astacus L. (Crustacea: Decapoda), Ecotox. Environ. Safe. 21 (1991) 137-156.

[73] L. Wang, B. Yan, N. Liu, Y.Q. Li, Q. Wang, Effects of cadmium on glutathione synthesis in hepatopancreas of freshwater crab, Sinopotamon yangtsekiense, Chemosphere 74 (2008) 51 56.

585 [74] R. Karmakar, S. Banik, S. Bandyopadhyay, M. Chatterjee, Cadmium-induced alterations of hepatic lipid peroxidation, glutathione S-transferase activity and reduced glutathione level and their possible correlation with chromosomal aberration in mice: a time course study, Mutat. Res.-Fundam. Mol. Mech. Mutagen. 397 (1998) 183-190.

[75] P. Manna, M. Sinha, P.C. Sil, Amelioration of cadmium-induced cardiac impairment by taurine, Chem.-Biol. Interact. 174 (2008) 88-97. 
[76] M. Sinha, P. Manna, P.C. Sil, Attenuation of cadmium chloride induced cytotoxicity in murine hepatocytes by a protein isolated from the leaves of the herb Cajanus indicus L, Arch. Toxicol. 81 (2007) 397-406.

[77] L.P. Fang, C.H. Xu, J. Li, O.K. Borggaard, D.S. Wang, The importance of environmental factors and matrices in the adsorption, desorption, and toxicity of butyltins: a review, Environ. Sci. Pollut. Res. 24 (2017) 9159-9173.

[78] S.M. Al-Ghais, B. Ali, Inhibition of glutathione-S-Transferase catalyzed xenobiotic detoxification by organotin compounds intropical marine fish tissues, Bulletin Environmental Contamination Toxicology 62 (1999) 207-213.

600

[79] R.A. Henry, K.H. Byington, Inhibition of glutathione-S-aryltransferase from rat liver by organogermanium, lead and tin compounds, Biochem. Pharmacol. 25 (1976) 2291-2295.

[80] J. Padros, E. Pelletier, C.O. Ribeiro, Metabolic interactions between low doses of benzo a pyrene and tributyltin in arctic charr (Salvelinus alpinus): a long-term in vivo study, Toxicol. Appl. Pharmacol. 192 (2003) 45-55.

[81] J.M. Goodrich, N. Basu, Variants of glutathione s-transferase pi 1 exhibit differential enzymatic activity and inhibition by heavy metals, Toxicol. Vitro 26 (2012) 630-635.

[82] A. Sen, A. Semiz, Effects of metals and detergents on biotransformation and detoxification enzymes of leaping mullet (Liza saliens), Ecotox. Environ. Safe. 68 (2007) 405-411.

[83] M.P. Gunderson, B.T. Nguyen, J.C.C. Reyes, L.L. Holden, J.M.T. French, B.D. Smith, C. Lineberger, Response of phase I and II detoxification enzymes, glutathione, metallothionein and acetylcholine esterase to mercury and dimethoate in signal crayfish (Pacifastacus leniusculus), Chemosphere 208 (2018) 749-756.

[84] R.S. Dwivedi, Lead exposure alters the drug metabolic activity and the homeostasis of essential metal ions in the lenticular system of the rat, Environ. Pollut. 94 (1996) 61-66.

[85] T. Nakahama, Y. Inouye, M. Fukuhara, Comparative study on in vitro inhibitory effects of heavy metals on rabbit drug-metabolizing enzymes, J. Health Sci. 47 (2001) 14-20.

[86] R. Hansch, R.R. Mendel, Physiological functions of mineral micronutrients ( $\mathrm{Cu}, \mathrm{Zn}, \mathrm{Mn}, \mathrm{Fe}$, Ni, Mo, B, Cl), Curr. Opin. Plant Biol. 12 (2009) 259-266.

[87] C. Jonak, H. Nakagami, H. Hirt, Heavy metal stress. Activation of distinct mitogen-activated protein kinase pathways by copper and cadmium, Plant Physiol. 136 (2004) 3276-3283.

[88] N. Ahsan, D.G. Lee, S.H. Lee, K.Y. Kang, J.J. Lee, P.J. Kim, H.S. Yoon, J.S. Kim, B.H. Lee, Excess copper induced physiological and proteomic changes in germinating rice seeds, Chemosphere 67 (2007) 1182-1193.

[89] L. Li, M.J. Hou, L. Cao, Y. Xia, Z.G. Shen, Z.B. Hu, Glutathione S-transferases modulate Cu tolerance in Oryza sativa, Environ. Exp. Bot. 155 (2018) 313-320.

[90] H. Teisseire, V. Guy, Copper-induced changes in antioxidant enzymes activities in fronds of duckweed (Lemna minor), Plant Sci. 153 (2000) 65-72.

[91] M.R. Broadley, P.J. White, J.P. Hammond, I. Zelko, A. Lux, Zinc in plants, New Phytol. 173 (2007) 677-702.

[92] A. Bittsanszky, T. Komives, G. Gullner, G. Gyulai, J. Kiss, L. Heszky, L. Radimszky, H. Rennenberg, Ability of transgenic poplars with elevated glutathione content to tolerate zinc(2+) stress, Environ. Int. 31 (2005) 251-254.

[93] W.H.O. Ernst, G.J. Krauss, J.A.C. Verkleij, D. Wesenberg, Interaction of heavy metals with the sulphur metabolism in angiosperms from an ecological point of view, Plant Cell Environ.

[94] M. Rother, G.J. Krauss, G. Grass, D. Wesenberg, Sulphate assimilation under Cd2+ stress in Physcomitrella patens - combined transcript, enzyme and metabolite profiling, Plant Cell Environ. 29 (2006) 1801-1811.

[95] L. Lyubenova, P. Schroder, Plants for waste water treatment - Effects of heavy metals on the detoxification system of Typha latifolia, Bioresour. Technol. 102 (2011) 996-1004. 
[96] A.R. Memon, P. Schroder, Implications of metal accumulation mechanisms to phytoremediation, Environ. Sci. Pollut. Res. 16 (2009) 162-175.

[97] Y.K. Markovska, N.I. Gorinova, M.P. Nedkovska, K.M. Miteva, Cadmium-induced oxidative damage and antioxidant responses in Brassica juncea plants, Biol. Plant. 53 (2009) 151-154.

[98] C.-h. Zhang, Y. Ge, Response of Glutathione and Glutathione S-transferase in Rice Seedlings Exposed to Cadmium Stress, Rice Science 15 (2008) 73-76.

[99] A. Guittonny-Philippe, V. Masotti, P. Höhener, J.-L. Boudenne, J. Viglione, I. LaffontSchwob, Constructed wetlands to reduce metal pollution from industrial catchments in aquatic Mediterranean ecosystems: A review to overcome obstacles and suggest potential solutions, Environ. Int. 64 (2014) 1-16.

[100] P. Schröder, C. Fischer, R. Debus, A. Wenzel, Reaction of detoxification mechanisms in suspension cultured spruce cells (Picea abies L. Karst.) to heavy metals in pure mixture and in soil eluates, Environ. Sci. Pollut. Res. 10 (2003) 225-234.

[101] A. Nepovím, R. Podlipná, P. Soudek, P. Schröder, T. Vanek, Effects of heavy metals and nitroaromatic compounds on horseradish glutathione S-transferase and peroxidase, Chemosphere 57 (2004) 1007-1015.

[102] S.G. George, P. Young, The time course of effects of cadmium and 3-methylcholanthrene on activities of enzymes of xenobiotic metabolism and metallothionein levels in the plaice, Pleuronectes platessa, Comp. Biochem. Physiol. C-Toxicol. Pharmacol. 83 (1986) 37-44.

[103] C.S. Liu, Y.B. Du, B.S. Zhou, Evaluation of estrogenic activities and mechanism of action of perfluorinated chemicals determined by vitellogenin induction in primary cultured tilapia hepatocytes, Aquat. Toxicol. 85 (2007) 267-277.

[104] J.H. Choi, W. Lou, A. Vancura, A novel membrane-bound glutathione S-transferase functions in the stationary phase of the yeast Saccharomyces cerevisiae, J. Biol. Chem. 273 (1998) 29915-29922.

[105] P.-J. Jakobsson, S. Thorén, R. Morgenstern, B. Samuelsson, Identification of human prostaglandin E synthase: A microsomal, glutathione-dependent, inducible enzyme, constituting a potential novel drug target, Proceedings of the National Academy of Sciences 96 (1999) 7220. 